\title{
Exploring logistics-related environmental sustainability in large retailers
}

Maria Björklund, Helena Forslund and Maria Persdotter Isaksson

The self-archived postprint version of this journal article is available at Linköping University Institutional Repository (DiVA):

http:// urn.kb.se/ resolve?urn=urn:nbn:se:liu:diva- 124187

N.B.: When citing this work, cite the original publication.

Björklund, M., Forslund, H., Persdotter Isaksson, M., (2016), Exploring logistics-related environmental sustainability in large retailers, International J ournal of Retail \&Distribution Management, 44(1), 38-57. https:// doi.org/ 10.1108/ IJ RDM-05-2015-0071

Original publication available at:

https:// doi.org/ 10.1108/IJ RDM-05-2015-0071

Copyright: Emerald

http:// www.emeraldinsight.com/ 


\title{
EXPLORING LOGISTICS-RELATED ENVIRONMENTAL SUSTAINABILITY IN LARGE RETAILERS
}

\author{
ABSTRACT \\ Purpose \\ The purpose of this study is to explore and illustrate ways in which the world's largest retailers \\ describe their logistics-related environmental considerations, their environmental indicators \\ applied to measure the effects of these considerations, and their environmental consciousness \\ in their CSR reports.
}

\section{Design/methodologylapproach}

Classification models are developed via a literature review on logistics-related environmental considerations, indicators and consciousness. A content analysis approach is then applied to examine CSR reports from twelve of the world's largest retailers.

\section{Findings}

Few retailers show environmental considerations in all logistics activities, and purchasing is especially well described. Even if many retailers claim to use the GRI framework, no one uses is completely. Judging consciousness from CSR reports raised a number of questions.

\section{Research limitations/implications}

A contribution to theory is the development of two classification models. The first provides a description structure for environmental considerations related to logistics activities. The second expands the GRI indicator framework by incorporating a structure for logistics activities.

\section{Practical implications}

The classification models developed can be an important mean for managers and also consumers to judge the environmental sustainability of retailers by their CSR reports.

\section{Social implications}

The study makes a social contribution with its input on sustainability and especially environmental issues.

\section{Originality/value}

Few studies have focused upon environmentally sustainable logistics in retailers, and even fewer address how to measure environmental sustainability in this context.

Keywords: Retailer, environmental sustainability, logistics, environmental indicator, consciousness 


\section{INTRODUCTION}

The retail sector is continuously growing, competition increasing, and logistics performance is critical (Menachof et al., 2009; Ganesan et al., 2009; McKinnon and Edwards, 2009; Fernie et al., 2010; ECR, 2011; Forslund, 2014). Considerations to sustainability are growing in importance due to, e.g., the trend towards global supply chains and increased stakeholder consciousness. Retailers alone might not have a large environmental impact, but they play an important role in securing sustainable behaviour in their supply chains (Kolk et al., 2010, Wiese et al., 2015). They are often held responsible for the actions of other actors, as they have contact with both consumers and suppliers (Spence and Bourlakis, 2009; Kolk et al., 2010; Kotzab et al., 2011; Wiese et al., 2015). Furthermore, due to their large size and the consolidation of bargaining power, retailers are described as having the power to change practices along the supply chain (Jones et al., 2005a, 2005b, Wiese et al., 2015). Studies such as Jones et al. (2005a, 2005b) have addressed retailers' sustainability practices broadly. As transport is the largest source of environmental impact in the logistics system (e.g. Abukhader and Jönson, 2004), logistics plays an important role in the work towards sustainable development (Seuring and Müller, 2008; Shaw et al., 2010; Abbasi and Nilsson, 2012). It seems therefore relevant to conduct a study focused on retailers' sustainability within logistics. Despite the importance of incorporating environmental sustainability into logistics, research within the field is relatively sparse (Seuring and Müller, 2008; Wiese et al., 2012). Not only is research lacking, there are also large practical needs. Working towards improved sustainability raises new managerial challenges for retailers (Elg and Hultman, 2011), such as the difficult task of judging supply chain partners' sustainability practices. This is a resource-consuming issue. To communicate sustainability, companies are increasingly issuing accessible CSR reports to stakeholders (Tate et al., 2010). It would be convenient if an understanding of environmental sustainability could be achieved from a CSR report.

In this article we have identified three important areas to consider when evaluating the sustainability practices of supply chain partners: First, what they do (i.e. environmental considerations). Ashby et al. (2012) and Wiese et al. (2012) call for an increased understanding of environmental considerations (or initiatives as labelled by Kotzab et al., 2011). Retailers' sustainability considerations are often described as both fragmented and unsystematic. There would be value in providing an overview of retailers' environmental considerations - what they do - related to logistics. Such knowledge could ease judgement and selection of supply chain partners, providing answers to such questions as: Q1a. In which logistics activities are environmental considerations undertaken by retailers? Q1b. Do they have a narrow or wide scope-i.e., are these considerations brought into few or many logistics activities? Second, what they measure (i.e. environmental indicators applied). More research is needed on how to measure sustainability considerations made by companies, in order for the measurement to become consensual, robust and less subjective (Shaw et al., 2010; Elg and Hultman, 2011; Abbasi and Nilsson, 2012). Retailers are expected to measure the effects of considerations undertaken, in order to ensure that the work towards more sustainable logistics has effects and is successful. Interpreting, operationalizing and measuring environmental sustainability in supply chains is challenging (Abbasi and Nilsson, 2012). Measuring environmental logistics performance in retail seems especially relevant, given the complexity present, with a large number of products and the length and number of retailers (Wiese et al., 2012). Björklund and Forslund (2013) found that companies who focus on environmental performance not necessarily consider how to measure it. Forslund (2014) found little interest for environmental performance indicators among retailers. We must consider, then, whether CSR reports can provide insight into questions targeting environmental indicators, such as: Q2a. For which 
logistics activities are environmental indicators found? Q2b. Which environmental indicators are commonly used? Q2c.Do retailers apply existing indicator frameworks? Third, why they do what they do (i.e. environmental consciousness). Not only may supply chain partners want to judge what companies do in terms of sustainability, they may also want to know why they do this. The environmental considerations and indicators applied by retailers may mirror the retailers' environmental consciousness. Environmental consciousness is seen in the level of maturity in the approaches, techniques, and strategies applied by organisations in the process of working towards sustainability (Benn et al., 2006). Companies can claim their proactive consciousness by having an environmental management system, however, they may still be focusing on compliance with legal demands and let production processes and products remain unchanged (Closs et al., 2011). Thus, the company can apply a very reactive consciousness. It is therefore important to dig deeper than the labels companies apply to themselves in order to consider their environmental consciousness (Ashby et al., 2012). An investigation regarding retailers' environmental consciousness ought to address questions such as: Q3a.How can environmental consciousness be classified? Q3b. What levels of consciousness are shown by retailers?

These three areas and the questions stated are used to address the overall purpose of this study: To explore and illustrate ways in which the world's largest retailers describe their logisticsrelated environmental considerations, their environmental indicators applied to measure the effects of these considerations, and their environmental consciousness in their CSR reports.

\section{FRAME OF REFERENCE}

A literature review was conducted to structure the empirical material and to frame the analysis. The review first describes how environmental considerations can be related to different logistics activities. Then studies measuring the effects of environmental considerations are reviewed and a framework of indicators is presented. The last section provides characteristics for three levels of consciousness.

\subsection{Environmental considerations in logistics activities}

There are a number of logistics activities that can incorporate environmental considerations. Wu and Dunn's (1995) commonly used model outlines a number of logistics activities that influence the environment, such as raw material acquisition, in- and outbound logistics, production, reverse logistics and marketing. In a paper addressing environmental supply chain management initiatives in retailing companies, Kotzab et al. (2011) identify eight broad environmental supply chain categories that include, under our terminology, both logistics activities (but not purchasing) and indicators (such as energy use). Inspired by two retail-based studies, Kotzab et al. (2011) and Bernon et al. (2011), we focus on purchasing, transport, warehousing and reverse logistics, as they are central logistics activities for a retailer and as they are often covered in sustainability reports. A literature review exemplifying environmental considerations in these logistics activities follows.

Purchasing includes considerations such as the location of suppliers, which affects e.g. transport distances (McKinnon, 2010). Carter and Jennings (2004) mention the design of suppliers' products and processes as a means to reduce environmental impact. For instance, the selection of material used in packaging is one factor that can influence environmental impact (Fernie et al., 2010). The suppliers' environmental process management could be influenced by requiring that suppliers have an environmental management system (EMS) (Björklund, 2010; Young and Kielkiewicz-Young, 2001). Other environmental considerations in purchasing include communicating sustainability policies and goals to suppliers and investing in education and 
training (Young and Kielkiewicz-Young, 2001). Transport is the largest source of environmental impact in the logistics system (Wu and Dunn, 1995; Abukhader and Jönson, 2004), raising such considerations as the selection of more efficient transport modes and increased use of intermodal transport solutions (Wu and Dunn, 1995; McKinnon, 2010; EngLarsson and Kohn, 2012). Technical solutions such as age, engines, and type of fuel used (Björklund, 2005; Weijers et al., 2012), selection of environmentally conscious transport suppliers (for example Sarkis et al., 2004; Björklund, 2005), and eco-efficient driving and maintenance can reduce the environmental impact (Wu and Dunn, 1995; Björklund, 2005; Aronsson and Huge-Brodin, 2006; McKinnon, 2010; Weijers et al., 2012). Logistics system design can incorporate more direct transports, continuously improve distribution networks, and decrease the average handling factor and average length of haul (Sarkis et al., 2004; McKinnon, 2010; Martinsen and Björklund, 2012). Transport management can imply planned routes and high fill-rates (McKinnon, 2010; Weijers et al., 2012). Transport includes the use of third party logistics providers, which in itself should have positive environmental effects on all the mentioned levels; mode selection/intermodal transport, technical solutions, transport supplier selection, eco-efficient driving, logistics system design and transport management (see also Table 1).

Warehousing is often overlooked in the discussion of sustainable logistics, but it has a significant environmental impact (Marchant, 2010), for instance through energy management with warehouse resources such as handling equipment, heating, lighting and ventilation (Marchant, 2010; Weijers et al., 2012). Location and capacity of warehouses were found to have a central influence on the possibilities for decreasing environmental impact (McKinnon, 2010; Aronsson and Huge-Brodin, 2006). Reverse logistics, where retailers have found themselves obliged by law to take back their own products, is a complex but essential aspect of sustainability (e.g. Bernon et al., 2011). Examples of environmental considerations include the selection of load carriers or the management of disposal (van Hoek, 1999; Rogers and TibbenLembke, 2001).

Table 1. Environmental considerations in logistics activities (operationalization shaded)

\begin{tabular}{|l|l|l|}
\hline Activities & Environmental considerations & Examples of central references \\
\hline Purcha- & -Location of suppliers & McKinnon (2010) \\
& -Design of purchased products & Carter and Jennings (2004); Fernie et al. (2010) \\
& -Supplier process design/EMS & Carter and Jennings (2004); Björklund (2010) \\
& -Communication of sustainability policies & Young and Kielkiewicz-Young (2001) \\
& -Training/education of suppliers & Young and Kielkiewicz-Young (2001) \\
\hline Transport & -Mode selection/intermodal transport & McKinnon (2010); Eng-Larsson and Kohn (2012) \\
& -Technical solutions & Björklund (2005): Weijers et al. (2012) \\
& -Transport supplier selection & Sarkis et al. (2004); Björklund (2005) \\
& -Eco-efficient driving & McKinnon (2010) \\
& -Logistics system design & Sarkis et al. (2004); Martinsen and Björklund (2012) \\
& -Transport management & McKinnon (2010); Weijers et al. (2012) \\
\hline $\begin{array}{l}\text { Ware- } \\
\text { housing }\end{array}$ & -Energy management & Marchant (2010); Weijers et al. (2012) \\
& -Location/capacity of warehouses & Aronsson and Huge-Brodin (2006), McKinnon \\
\hline Reverse & (2010) \\
logistics & -Selection of load carriers & van Hoek (1999); Rogers and Tibben-Lembke (2001) \\
\hline
\end{tabular}

\subsection{Environmental indicators}

In an extensive study of retail supply chain executives, performance measurement was identified as one key area for future competitiveness (ECR, 2011). Jones et al. (2005b) found that a majority of UK's top 20 retailers seek to measure, benchmark and compare their sustainability 
performance, and that some of them develop their own performance indicators. Due to global competition, retailers are increasingly interested in measuring performance, particularly logistics performance (Ganesan et al., 2009). Kotzab et al. (2011) state that environmental sustainability is easy to demand, but difficult to measure. Elg and Hultman (2011) found, based upon a survey study of Swedish retailers, few retailers providing systematic reporting of environmental performance. The same pattern was found in another retail study by Forslund (2014). Environmental indicators are continuously developing and various systems have been proposed, but there is no universally accepted system (Jones et al., 2005b; Shaw et al., 2010; Searcy, 2011). Bernon et al. (2011) relate retail reverse logistics to operational performance, but comment on the difficulties in finding indicators. Shaw et al. (2010) studied the development of environmental supply chain indicators in a literature study and found the number of studies to grow considerably over the years. In search of standardized indicators, they described ISO 14001 "Requirements with guidance for use" and the performance evaluation tool ISO 14031. However they found that the indicators used in ISO14031 are variable across organizations and not for public disclosure. In contrast, Shaw et al. (2010) described Global Reporting Initiative (GRI) which was developed in order to provide a framework for reporting, exchanging and comparing sustainability performance. An increase acceptance and use of this standardized framework was found. Consequently, GRI is the indicator framework that we expect to find.

The GRI G4 version is the latest update of the GRI's Sustainability Reporting Guidelines (www.globalreporting.org, 2014). The environmental dimension of the GRI incorporates twelve indicators, which are used to operationalize environmental indicators are shown in Table 2 together with their specifications. They are not structured in a way so the GRI indicators could be related to logistics activities, and it is even more difficult to relate them to environmental considerations.

Table 2. Environmental indicators (operationalization shaded)

\begin{tabular}{|l|l|}
\hline Environmental indicators & Specification \\
\hline Materials & Used, recycled \\
Energy & Consumption \\
Water & Withdrawal, recycled, reused \\
Biodiversity & Protected areas, red lists \\
Emissions & Greenhouse gas \\
Effluents and waste & Discharge, waste \\
Products and services & Environmental impact \\
Compliance & Fines, sanctions \\
Transport & Environmental impact \\
Overall & Protection expenditures, investments \\
Supplier environmental assessment & \% of new suppliers screened, impact/actions in the supply chain \\
Environmental grievance mechanisms & Number of grievances \\
\hline
\end{tabular}

www.globalreporting.org, 2014

\subsection{Levels of environmental consciousness}

Retail companies' consciousness about the planet's environmental threats is increasing (McKinnon and Edwards, 2009). The levels (or stages) of maturity in the approaches, techniques, and strategies applied by organisations is described in the literature represent a set of ideal types, which can be used to define the current level of consciousness in considerations or in the organisation. The number of levels and their labels differ between different studies, but the levels typically fall along a continuum ranging from resistant or defensive to more value- 
seeking and competitive advantage-oriented (Benn et al., 2006; Tate et al., 2010). Highly detailed stages may be difficult to identify in sustainability reports. Furthermore Tate et al. (2010) note that the level of consciousness expressed in sustainability reports may be higher than the level of actual implementation, and that these reports might only focus on the positives and are used as a marketing tool for the company to enhance image among stakeholders. Carbone et al. (2012) mean that even if companies increasingly proclaim their environmental concerns, they have been accused of "greenwashing", i.e. use green words rather than taking green actions. To handle this risk, we use three broader categories in a classification framework. We are also aware about the greenwashing tendencies in our analysis. Our strive to operationalize environmental consciousness is presented in Table 3.

Companies with a reactive consciousness aim towards compliance with existing laws and regulations associated with sustainability, but they seldom make sustainability investments beyond the compliance minimum (Closs et al., 2011). They may also undertake initiatives in response to public protest (McKinnon, 2010). The aim for companies is to achieve cost savings, and the non-economic dimensions of sustainability are seen as low priority and are commonly excluded from the decision-making process (Benn et al., 2006; Closs et al., 2011). These companies attempt to, e.g., influence the market by convincing customers through green promotion of their product in combination with a clear price focus (Brindley and Oxborrow, 2014).

Companies with a proactive consciousness have typically recognised the strategic importance of environmental performance. They focus heavily on their own supply chain, striving to synergistically enhance sustainability, particularly with suppliers (Closs et al. 2011). These companies can apply risk management to identify sustainability problems before these are exposed publicly, and include the total life cycle of the product in their practices (Seuring, 2008). They can rely on industry or cross-industry sustainability benchmarking to identify potential initiatives (Closs et al., 2011). Furthermore, these companies strive to pre-empt new laws by, e.g., voluntarily starting programs (Ashby et al., 2012), and they form relationships with different legislators to, e.g., address environmental issues (Carter and Ellram, 1998). When it comes to community involvement, these companies strive to participate, but are less likely to initiate such practices (Closs et al. 2011).

Companies with a value-seeking consciousness strive to integrate sustainability activities into the business strategy, and their contribution to sustainability is described as a strategic priority (Closs et al., 2011; Ashby et al., 2012). Gaining competitive advantage through sustainability performance is central. It is necessary to make the environment a key element in the business model in order to extract more value from the adoption of green practices (McKinnon, 2010). These companies often seek best practice performance and changes that positively benefit their stakeholders, the industry and surrounding communities. They typically take a long-term perspective and their initiatives are viewed as longer-term firm investments (Closs et al., 2011). Human capital is used to develop strategic advantage through innovation in products and services (Benn et al., 2006). Tate et al. (2010) also propose that companies that create progressive corporate environmental strategies cut across all aspects of sustainable practices. These organizations are driven by market changes and demand, and they strive to influence customers by realizing customer benefits in the green product (Brindley and Oxborrow, 2014).

Table 3. Characteristics for three levels of environmental consciousness

\begin{tabular}{|l|l|l|}
\hline Reactive consciousness & Proactive consciousness & Value-seeking consciousness \\
\hline $\begin{array}{l}\text {-Compliance with laws and } \\
\text { regulations }\end{array}$ & $\begin{array}{l}\text {-Recognizing strategic importance } \\
\text {-Enhancing sustainability with } \\
\text { suppliers }\end{array}$ & $\begin{array}{l}\text {-Sustainability in business strategy } \\
\text {-Sustainability is key element in } \\
\text { business model }\end{array}$ \\
\hline
\end{tabular}




\begin{tabular}{|l|l|l|}
\hline -Compliance with public & -Proactive problem solving & -Long-term investments \\
protest & -Sustainability benchmarking & -Human capital innovating products \\
-Cost savings/price focus & -Pre-empting new laws & -Covering all aspects of \\
-Convincing & -Participation in community & sustainability \\
customers/green promotions & -Realizing customers' benefits \\
& involvement & -Initiating community involvement \\
& & programs \\
\hline
\end{tabular}

\section{METHODOLOGY}

To offer a broad overview with a global scope, the world's largest retailers (belonging to large retail chains) are targeted. Large retailers were selected since these are likely to have more resources to devote to sustainability measuring and reporting, and thereby present more comprehensive reports. When searching for a sampling frame, many searches landed on the same webpage (www.stores.org), and its “Top 250 global retailers" list. Not every retailer is expected to have a CSR report. We had to study the thirteen largest retailers (by sales rank) in order to find ten retailers having a CSR report. Then we wished to add another two reports to see if saturation was reached. This required another three retailers, since one did not report on their sustainability work. As this second search did not result in any changes in our conclusions drawn, we claim that studying twelve retailers has implied that saturation was reached. This also implies that we can claim higher external validity. We have studied the 16 largest retailers, in order to find 12 CSR reports (75\%). According to Tate et al. (2010), in 2007 close to 60\% of the top 200 global companies had CSR reports and this number is continuously increasing. Our study seems to support this increase. The retailers and their characteristics are shown in Table 4.

Table 4. Characteristics of retailers studied

\begin{tabular}{|l|l|l|l|l|l|l|}
\hline $\begin{array}{l}\text { Sales } \\
\text { Rank }\end{array}$ & Retailer & $\begin{array}{l}\text { Country of } \\
\text { Origin }\end{array}$ & Dominant Format & Name of report & Pages & $\begin{array}{l}\text { Reporting } \\
\text { Standard }\end{array}$ \\
\hline 1 & Wal-Mart Stores & U.S. & Hypermarket & Global Responsibility Report & 174 & GRI \\
\hline 2 & Carrefour & France & Hypermarket & Annual activity and responsible commitment report & 76 & - \\
\hline 3 & Tesco & U.K. & Hypermarket & Tesco and Society & 64 & - \\
\hline 4 & Metro & Germany & Cash \& Carry Warehouse & Sustainability Report & 97 & GRI \\
\hline 5 & The Kroger Co. & U.S. & Supermarket & Sustainability Report & 69 & GRI \\
\hline 6 & Costco & U.S. & Cash \& Carry Warehouse & Corporate Sustainability Report & 36 & - \\
\hline 10 & The Home Depot & U.S. & Home Improvement & Sustainability Brochure & 15 & - \\
\hline 11 & Target & U.S. & Discount Store & Corporate Sustainability Report & 118 & GRI \\
\hline 12 & Groupe Auchan & France & Hypermarket & Sustainability Report & 52 & - \\
\hline 13 & Aeon Co & Japan & Hypermarket & Sustainability Report & 94 & GRI \\
\hline 14 & CVS Caremark Corp. & U.S. & Drug Store/Pharmacy & Corporate Social Responsibility Report & 86 & GRI \\
\hline 16 & Seven \& i Holdings Co & Japan & Convenience Store & Corporate Social Responsibility Report & 77 & GRI \\
\hline
\end{tabular}

Adapted from Top 250 Global Retailers - www.stores.org

The most recent CSR reports were downloaded from the companies' homepages. Tate et al. (2010) found the average length of a CSR report to be 65 pages. The reports in our study varied highly from 15 to 174 pages, with an average length of 80 pages. This can be interpreted as an increase as compared to the study by Tate et al. (2010).

Content analysis is applied to systematically and objectively evaluate, categorize and synthesize information in written text (Bryman and Bell, 2011). It is useful for understanding text in three ways: the text itself (what is said in CSR reports), the audience (stakeholders and supply chain 
partners) and the creator (the reporting retailers) (Tate et al., 2010). To ensure the quality of the content analysis, the guidelines from Seuring and Gold (2012) were followed. A necessary beginning is the development of research questions/purpose (Bryman and Bell, 2011; Seuring and Gold, 2012). The purpose of this study was to examine CSR reports (sampling media) showing the considerations taken, the environmental indicators applied and the ways in which consciousness is shown in large retailers.

A content analysis requires that the rules for what to include, or keywords, are specified in advance (Bryman and Bell, 2011; Seuring and Gold, 2012). By using the advanced search function in Adobe Acrobat, the following keywords for the first search (for text related to logistics activities) were applied. Purchasing (purchas*, supply, procur*, supplier, vendor, sourc*), transport (transport*, freight, distribution), warehousing (warehous*) and reverse logistics (reverse logistics, return, disposal, recycle). Text that contained the respective keywords was copied into four large word files, one for each logistics activity. Within each such wordfile, a second search for environmental considerations was conducted based upon the keywords/operationalization in Table 1. A third search went back to the original wordfile for environmental indicators, it was conducted based upon the keywords/operationalization in Table 2. Specifying keywords for the second and third search was more difficult due to the vocabulary of the reports; the Adobe Acrobat search had to be complemented with ocular searches for synonyms. This is referred to as "latent content" by Bryman and Bell (2011, p. 290). The second and third search resulted in the copying of text on considerations and indicators into two large (20-40 pages each) documents. From them we could count the existence of considerations and indicators (shown in Tables 5 and 7). From this text we also copied quotations selected as illustrative examples (shown in Tables 6 and 8).

A fourth search for characteristics of consciousness was conducted based upon the keywords in Table 3, however very little information about consciousness was found within the logisticsrelated text. Instead we had to go back to the CSR reports and use the characteristics of consciousness as keywords, searching in general text. Three researchers conducted the first third of the second, third and fourth search together, within a short time period in order to achieve inter-rater reliability. The remaining search was conducted by at least two researchers together, following the guidelines of Seuring and Gold (2012). This was, as indicated by Bryman and Bell (2011), time-consuming but necessary for accuracy and reliability. The unit of analysis (Bryman and Bell, 2011; Seuring and Gold, 2012) is the CSR report of each retailer. The analysis in the second, third and fourth search was carried out in a "cross-report" manner; we did not study considerations, indicators and each retailer "within-report”.

\section{FINDINGS AND ANALYSIS}

This section is structured as the frame of reference in environmental considerations, indicators and consciousness. The presentation of the findings is structured around the questions posed in the introduction.

\subsection{Environmental considerations in logistics activities}

The vertical dimension in Table 5 shows with " $X$ " the existence of considerations described in purchasing, transport, warehousing and reverse logistics for each retailer (Q1a).

Table 5. Environmental considerations in logistics activities 


\begin{tabular}{|c|c|c|c|c|c|c|c|c|c|c|c|c|c|c|c|}
\hline $\begin{array}{l}\text { Logistics } \\
\text { activities }\end{array}$ & Environmental considerations & R1 & R2 & R3 & R4 & R5 & R6 & R10 & R11 & R12 & R13 & R14 & R16 & Sum & Sum/act \\
\hline \multirow[t]{5}{*}{ Purchasing } & -Location of suppliers & $\mathrm{X}$ & $\mathrm{X}$ & $\mathrm{X}$ & $\mathrm{X}$ & $\mathrm{X}$ & $\mathrm{X}$ & & & $\mathrm{X}$ & $\mathrm{X}$ & $X$ & & 9 & 48 \\
\hline & -Design of purchased products & $\mathrm{X}$ & $\mathrm{X}$ & $\mathrm{X}$ & $\mathrm{X}$ & & & $\mathrm{X}$ & $\mathrm{X}$ & & $\mathrm{X}$ & $\mathrm{X}$ & $\mathrm{X}$ & 9 & \\
\hline & -Supplier process design/EMS & $\mathrm{X}$ & $\mathrm{X}$ & $\mathrm{X}$ & & & $\mathrm{X}$ & & $\mathrm{X}$ & $\mathrm{X}$ & $\mathrm{X}$ & $\mathrm{X}$ & $\mathrm{X}$ & 9 & \\
\hline & $\begin{array}{l}\text {-Communicate sustainability } \\
\text { policies to suppliers }\end{array}$ & $\mathrm{X}$ & & $X$ & $\mathrm{X}$ & $\mathrm{X}$ & $\mathrm{X}$ & $X$ & $\mathrm{X}$ & & $X$ & $\mathrm{X}$ & $\mathrm{X}$ & 10 & \\
\hline & $\begin{array}{l}\text {-Training and education of } \\
\text { suppliers }\end{array}$ & $\mathrm{X}$ & $\mathrm{X}$ & $\mathrm{X}$ & $\mathrm{X}$ & $\mathrm{X}$ & $\mathrm{X}$ & $\mathrm{X}$ & $\mathrm{X}$ & $\mathrm{X}$ & $\mathrm{X}$ & $\mathrm{X}$ & & 11 & \\
\hline \multirow[t]{6}{*}{ Transport } & \begin{tabular}{|l}
-Mode selection/intermodal \\
transportation \\
\end{tabular} & & $\mathrm{X}$ & & & & & & & $\mathrm{X}$ & $\mathrm{X}$ & & & 3 & 29 \\
\hline & -Technical solutions & $\mathrm{X}$ & & & & $\mathrm{X}$ & $\mathrm{X}$ & & $\mathrm{X}$ & & $\mathrm{X}$ & $\mathrm{X}$ & $\mathrm{X}$ & 7 & \\
\hline & -Transport supplier selection & & & & & & & & & & & & & 0 & \\
\hline & -Eco-efficient driving & $\mathrm{X}$ & & & & & & & & & $\mathrm{X}$ & & $\mathrm{X}$ & 3 & \\
\hline & -Logistics system design & $\mathrm{X}$ & & & & & & & & $\mathrm{X}$ & $\mathrm{X}$ & $\mathrm{X}$ & $\mathrm{X}$ & 5 & \\
\hline & -Transport management & $\mathrm{X}$ & $\mathrm{X}$ & & & $\mathrm{X}$ & $\mathrm{X}$ & $\mathrm{X}$ & $\mathrm{X}$ & $\mathrm{X}$ & $\mathrm{X}$ & $\mathrm{X}$ & $\mathrm{X}$ & 10 & \\
\hline \multirow[t]{2}{*}{ Warehousing } & -Management of energy & $\mathrm{X}$ & $\mathrm{X}$ & $\mathrm{X}$ & $\mathrm{X}$ & & $\mathrm{X}$ & $\mathrm{X}$ & $\mathrm{X}$ & $\mathrm{X}$ & $\mathrm{X}$ & $\mathrm{X}$ & $\mathrm{X}$ & 11 & 16 \\
\hline & $\begin{array}{l}\text {-Location and capacity of } \\
\text { warehouses }\end{array}$ & & $X$ & & & & $\mathrm{X}$ & & & $\mathrm{X}$ & $X$ & $\mathrm{X}$ & & 5 & \\
\hline \multirow[t]{2}{*}{ Reverse logistics } & -Selection of load carriers & $\mathrm{X}$ & & & & & $\mathrm{X}$ & & $\mathrm{X}$ & $\mathrm{X}$ & $\mathrm{X}$ & & & 5 & 12 \\
\hline & -Management of disposal & $\mathrm{X}$ & & & $\mathrm{X}$ & & $\mathrm{X}$ & & $\mathrm{X}$ & & $\mathrm{X}$ & $\mathrm{X}$ & $\mathrm{X}$ & 7 & \\
\hline Sum & & 12 & 8 & 6 & 6 & 5 & 10 & 5 & 9 & 9 & 14 & 11 & 9 & & 105 \\
\hline
\end{tabular}

Purchasing is the logistics activity that gets the highest score; 48 individual examples of considerations were found in the five environmental considerations investigated. Four retailers (R1, R3, R13 and R14) show all purchasing considerations, four retailers have four, and four have three. As one purpose of the study is to illustrate practices, some quotations concerning environmental considerations from CSR reports are provided in Table 6. Transport is the second most frequently described activity, with a score of 29 distributed among six considerations. Still, the average retailer will not include even half of the considerations. The highest score in transport is found in R13, who describes five considerations. Transport management is the consideration that was targeted by the most (ten) retailers, as seen in Table 5, while the other considerations regarding transport were seldom applied. For instance, there were only three sightings of mode selection/intermodal transport, and transport supplier selection was surprisingly - not mentioned by any retailer. Purchasing (five considerations) and transportation (six considerations) had a similar number of considerations in the literature, while it is interesting to note that purchasing demonstrates twice as many considerations as transport in the CSR reports. Warehousing contains just two considerations drawn from the literature, and the retailers scored 16. Management of energy was targeted by several retailers, while location/capacity of warehouses, a central consideration, appeared in only a few of the reports (see Table 5). Reverse logistics contains two considerations from the literature; we noted 12 considerations used among the 12 retailers. R1, R6, R11 and R13 describe both considerations. Reverse logistics is the logistics activity that is least described in the CSR reports.

Table 6. Illustrating environmental considerations in logistics activities

\begin{tabular}{|l|l|l|}
\hline Activities & $\begin{array}{l}\text { Environmental } \\
\text { considerations }\end{array}$ & Illustrating examples \\
\hline $\begin{array}{l}\text { Purcha- } \\
\text { sing }\end{array}$ & $\begin{array}{l}\text { Location of suppliers } \\
\text { “Our customers value the 'locally grown' and 'locally produced’ } \\
\text { programs as these products /.../ help lessen the impact /.../ through } \\
\text { reduced transportation and minimized handling” (R5, p16). }\end{array}$ \\
\hline
\end{tabular}




\begin{tabular}{|l|l|l|}
\hline Transport & $\begin{array}{l}\text { Mode selection/ } \\
\text { intermodal transport } \\
\text { Logistics system design } \\
\text { Transport management }\end{array}$ & $\begin{array}{l}\text { "[I]ncrease the use of /.../ multimodal transport combining rail/road or } \\
\text { river/ road” (R2, p22). } \\
\text { "[D]epots are strategically located /.../ to provide the most efficient } \\
\text { routes of transport” (R6, p24). } \\
\text { "The depots' emphasis on load maximization ...significantly reduce } \\
\text { trailer usage, fuel, and emissions.” (R6, p24). }\end{array}$ \\
\hline $\begin{array}{l}\text { Ware- } \\
\text { housing }\end{array}$ & $\begin{array}{l}\text { Management of energy } \\
\text { Location/capacity of } \\
\text { warehouses }\end{array}$ & $\begin{array}{l}\text { "[We] use the cooling power of snow for preservation of potatoes after } \\
\text { harvest” (R13, p33)" } \\
\text { "[To] reduce its carbon footprint, [we work] to optimise its logistics } \\
\text { activities. Its initiatives include sharing warehouses to reduce the } \\
\text { distances travelled.” (R2, p63) }\end{array}$ \\
\hline $\begin{array}{l}\text { "[We] use reusable containers in our reverse logistics business, } \\
\text { Reverse } \\
\text { logistics }\end{array}$ & Selection of load carriers our use of traditional wood pallets” (R11, p20) \\
\hline
\end{tabular}

Table 5 also provides insights regarding the scope (Q1b) of the considerations. A full score in our model would imply 15 considerations. The "best case," R13, scores 14 and the "worst cases," R5 and R10, both score 5. Six of the retailers scored higher than the average score of 8 . Remembering that we have studied the world's largest retailers, this is disappointing. Taking into consideration that "greenwashing" might exist, thus that the companies use green words rather than taking green actions (Tate et al., 2010 and Carbone et al., 2012), the results are even more disappointing. Overall, we can see that seven of the retailers (R1, R6, R11, R12, R13, R14 and R16) show considerations in all four logistics activities. Three of the chains describe considerations in three activities, excluding either reverse logistics (R2 and R10), or transportation (R4). Two of the chains have considerations in just two logistics activities, excluding transportation and reverse logistics (R3) or warehousing and reverse logistics (R5). We can consequently see vastly differing scopes in the studied retailers, and it is difficult to see any patterns in terms of scope.

\subsection{Environmental indicators}

The existence of environmental indicators found in logistics activities (Q2a) for each retailer (numbers as from Table 4) is illustrated in Table 7. The retailers that show certain indicators in certain activities are listed in each box. Table 7 shows that environmental indicators are used in all four logistics activities studied. Ten retailers (R1, R2, R3, R4, R6, R11, R12, R13, R14 and R16) have at least one indicator in each of the four activities. Purchasing is the logistics activity where the most indicators were found, especially measuring emissions, materials and products/services. Transport is second; emissions are also considered here. This is the same pattern as for the considerations shown in 4.1, where purchasing was the most prominent. We can therefore see, on a "cross-case" level, a relation between retailers' environmental considerations and indicators.

Table 7. Environmental indicators found related to logistics activities 


\begin{tabular}{|c|c|c|c|c|c|}
\hline GRI Indicators & Purchasing & Transport & Warehousing & Reverse logistics & Sum \\
\hline Materials & $1,2,3,4,12,13,14,16$ & $1,5,11$ & 13 & $1,12,14$ & 15 \\
\hline Energy & $1,2,12,13,14,16$ & $1,2,3,5,6,10,11,13,14,16$ & $1,2,6,13,14,16$ & $1,2,16$ & 25 \\
\hline Water & & & $3,4,13,14,16$ & & 5 \\
\hline Biodiversity & 16 & & & & 1 \\
\hline Emissions & $1,2,3,4,5,6,10,11,12,13,14,16$ & $1,2,3,4,5,6,10,11,12,13,14,16$ & $1,2,3,4,5,6,10,11,12,13,14,16$ & $1,3,4,6,11,13,14,16$ & 44 \\
\hline Effluents/waste & $1,3,16$ & 1 & $1,13,14,16$ & $1,12,16$ & 11 \\
\hline Products/service & $1,2,4,5,11,13,14,16$ & $1,2,11,14$ & 13 & & 16 \\
\hline Compliance & & & & & 0 \\
\hline Transport & & $1,2,5,11,12,13,14,16$ & 13 & & 10 \\
\hline Overall & $1,4,6,10,11,14,16$ & $1,4,5,6,10,11$ & $1,4,6,10,11,13,16$ & 1,4 & 22 \\
\hline Suppl env assess & 2,14 & & & & 2 \\
\hline Envgrievance & & & & & 0 \\
\hline Sum/activity & 47 & 44 & 37 & 19 & \\
\hline
\end{tabular}

Common indicators (Q2b) are addressed in Table 7, showing that emissions, energy and overall indicators are the most frequent indicators. For the GRI indicator transport, we have chosen to present the indicators that could be related to environmental impact, but were not yet covered by the other environmental indicators, i.e. materials and energy. However, two indicators from the GRI framework are not addressed by any retailer: compliance and environmental grievance mechanisms. We note a substantial focus on indicators related to reducing disposable plastic checkout bags; however, this indicator is not clearly related to logistics and therefore has not been included in Table 7. No retailer addresses all 12 GRI indicators. The "best-practice" retailers from Table 7 are R14 and R16, both describing nine indicators, and R13 describing eight, while R10 just describes three. Illustrations of environmental indicators, and to some extent guiding examples on ways to address them, are provided in Table 8. Instead of showing the most commonly applied and easy-to-find indicators, the examples in the table focus on the indicators more seldom applied.

Table 8. Illustrating environmental indicators in logistics activities

\begin{tabular}{|l|l|l|}
\hline Indicator & Activity & Illustrating example \\
\hline Water & Warehousing & $\begin{array}{l}\text { "[We] measure both our total use (m3) and water intensity (m3/ } \\
\text { square foot) of our stores and distribution centres” (R3, p42). }\end{array}$ \\
\hline Effluent/ waste & $\begin{array}{l}\text { General } \\
\text { Reverse } \\
\text { logistics }\end{array}$ & $\begin{array}{l}\text { "[We] diverted more than 96 percent of operational waste from } \\
\text { landfills" (R1, p149). } \\
\text { "We will work with suppliers to drive customer returns on defective } \\
\text { merchandise virtually out of existence (less than 1 percent) by the end } \\
\text { of 2012” (R1, p152). }\end{array}$ \\
\hline $\begin{array}{l}\text { Supplier } \\
\text { environmental } \\
\text { assessment }\end{array}$ & $\begin{array}{l}\text { "Percentage of new supplier that were screened using environmental } \\
\text { criteria" (R14, p14). }\end{array}$ \\
\hline
\end{tabular}

Q2c addressed the use of existing frameworks. As shown in Table 4, a majority or seven retailers used the GRI framework as reporting format. The remaining retailers mentioned the use of many other certifications (however not the expected ISO14031), methods, declarations and protocols, both official and company-internal ones.

\subsection{Environmental consciousness}

The literature review provided clear and similar ways of classifying environmental consciousness (Q3a), spanning from a reactive approach to a more value-seeking approach. In practice, and based only on the content of the sustainability reports, classifying the retailers' 
environmental consciousness was difficult for several reasons. Firstly, the sustainability reports provide a scattered picture of the logistics-related environmental considerations actually undertaken. Due to the lack of logistics-related information, we had to study environmental consciousness on a more general company level. Secondly, the reports seldom describe the underlying strategic reasons - the why - for environmental considerations. Thirdly, when the underlying motives are presented, we found that a single retailer could have characteristics of consciousness on all three levels. In such cases, we have classified each retailer as belonging to the level where it shows the most consciousness characteristics. We must also acknowledge that the data in this study depicts what retailers write in their CSR reports, not necessarily what they do, and it is here where we see the largest risk of greenwashing (e.g. Carbone et al., 2012) descriptions. Most reports we classified as being in-between the reactive and value-seeking levels, i.e. the reports suggest that these retailers have a proactive consciousness. The reports of four of the retailers (R10, R11, R12, R13) represent companies on the other end of the consciousness spectrum, i.e. suggesting a value-seeking consciousness. We exemplify consciousness on different levels in the text below.

\subsubsection{Reactive consciousness}

Several retailers are guided by national objectives and strategies; however, few address compliance with laws and regulations. Cost saving/price focus is addressed on a general level with statements such as, " $[\mathrm{H}]$ as been optimizing its responsible sourcing strategy at [the] global level to reduce its impact on the ecosystem and biodiversity, and to increase the economic sustainability of its operations" (R2, p38). The economical factor is also used to convince customers/use of green promotions: "We advise our customer to enable them to make sustainable purchasing decisions. That pays - both in their wallet and for the environment." (R4, p40).

\subsubsection{Proactive consciousness}

The strategic importance of environmental performance is recognized by several of the retailers. For example, one writes, "For the past twenty years, the Group has been optimizing its responsible sourcing strategy at global level to reduce its impact on the ecosystem and biodiversity" (R2, p38). Enhancing sustainability with suppliers is addressed in several retailers' reports. For example, a company claims they "want deeper relationships, with more skill and insight, enabling more investment and innovation - on both sides” (R3, p37). Proactive problem solving is often exemplified in the reports by the testing and use of new, more environmentally friendly technology. One example is a company that has "been active in the search for and testing of viable alternative vehicle fuels for more than 20 years" (R1, p59). Sustainability benchmarking is put forward by "bringing together more than 360 members across the supply chain, and suppliers to raise industry standards and improve sourcing practices” (R5, p24). If and how the studied retailers strive to pre-empt new laws is not clearly described in the reports. However, examples can be found of how collaborating with authorities can give the retailer an important role in designing the future development. R3 offered one example in how they "are working with the UK Government's Technology Strategy Board to explore how combining diesel with biogas can reduce emissions." The participation in community involvement can be exemplified by a company that notes, "In 2012, we began working with Cooperativa Finca El Pongo, a group of about 80 small farmers in the city of Perico" (R1, p68). 


\subsubsection{Value-seeking consciousness}

How sustainability is integrated in the business strategy is seldom described in the reports. One exception identified that "The Sustainability Integration System provides a forum for business unit reporting to measure and highlight a wide range of sustainability goals, achievements and improvements. It connects our individuals, teams, decisions and actions to our overall goal of sustainability" (R10, p7). Key elements in business model is difficult to identify but is exemplified in the statement, "The Group is acutely aware of new trends in food purchasing and consumption, which lean towards healthier products and place more emphasis on local, seasonal produce from sustainable production systems” (R12, p5). Long-term investments are illustrated by a company that is "preparing to roll out an energy saving programme with all its transporters. In exchange for energy economy certificates, the brand is funding various measures to enable its suppliers to improve their energy performance” (R12, p18), as well as "participating in environment related research and other gatherings held by governments, logistics operators, natural gas companies, automobile makers, universities, etc. organize environmental vehicle research meetings and rail transport research meetings, furthering our pursuit of adopting heavy duty gas vehicles and expanding our modal shift in transportation" (R13, p33). When it comes to realizing customers' benefits, one company states, “An increasing number of consumers are not simply interested in the quality and safety of the products they buy - they also want to know about their social and ecological compatibility” (R4, p45).

\section{DISCUSSION}

By suggesting a classification model that relates environmental considerations to logistics activities (Table 5), we have provided an increased, logistics-related understanding of environmental considerations, as demanded by e.g. Ashby et al. (2012). This state-of-the-art description of the world's largest retailers' work with environmental sustainability related to logistics, together with the provided quotations, illustrates environmental considerations at work and can inspire retailers and other supply chain partners. Our findings are in line with the findings of Jones et al. (2005a, 2005b) and Kotzab et al. (2011); that a majority of retailers address environmental sustainability but with substantial variation. We see a value for both practitioners and researchers in the model, as it provides an overview of important areas seldom targeted such as transport supplier selection, mode selection and eco-driving. Just five of the world's largest retailers have a broad scope and cover all four areas of logistics activities with their environmental considerations. Purchasing is by far most fully covered while transport, warehousing and reverse logistics receive comparably less emphasis. This is surprising, as the literature provided most considerations in transport, and transport is considered the most significant source of environmental impact in the logistics system (Wu and Dunn, 1995; Abukhader and Jönson, 2004). Reverse logistics should be an obligation for retailers by legislation (Bernon et al., 2011), yet it was found to be the logistics activity with the fewest considerations in sustainability reports. These findings are difficult to relate to previous research; one similar study by Kotzab et al. (2011) used a different structure for categorizing considerations and did not cover purchasing. One could therefore question why these reports do not show more environmental considerations in logistics activities; more than half of the studied retailers have a narrow scope and only address half of the logistics activities identified in the literature. The depth in their considerations varies highly among the retailers. This accords to Kotzab et al. (2011) who found that no studied retailer had a full set of considerations, and had overall large variations among them.

The GRI indicator standard (www.globalreporting.org) was developed and complemented by a structure for logistics activities (Table 7), which is another contribution of the study. Energy 
and emissions are frequent indicators, in line with the findings of Shaw et al. (2010) and Kotzab et al. (2011). However, many of the studied retailers do not show clear indicators. Instead they make general statements, such as "Minimize number of deliveries of product to our warehouses by consolidation of freight at our distribution centers and maximizing the load per truck". No retailer describes all 12 GRI indicators. The best-practice retailer in this context describes eight. This seems to support the findings of Elg and Hultman (2011), who found that few retailers provide systematic reporting of environmental performance, and Forslund (2014), who found a weak interest for environmental indicators among retailers. It also supports Jones et al. (2005a, 2005b) and Searcy (2011), who claim that no universally accepted measurement system exists. We found that four retailers use the GRI framework without commenting on it. We believe that this serves as evidence that no retailer covered all indicators, for they chose to exclude those they did not wish to comment upon. The most indicators were surprisingly found in purchasing, not in transport being the single largest source of environmental impact on the logistics system (Abukhader and Jönson, 2004). We found no clear link or alignment between considerations and indicators, which supports the statement of Kotzab et al. (2011) that environmental sustainability is easy to demand but difficult to measure. This area calls for future research as there is a need for guidance, tools, and methods in order to improve performance measurement within sustainable logistics.

When it comes to environmental consciousness, we found only three retailers that would be classified as value-seeking. In particular, the characteristic "key elements in business models" was difficult to find. This indicates a future research need in order to identify the elements in the business model of largest relevance with regard to this. Classification was challenging with the current methodology. We agree with Ashby et al. (2012) in their claim that it is necessary to go behind the labels the companies apply to themselves. Consciousness is a very complex matter to judge, and many difficult situations appear in this context. If a company has both reactive (the lowest level) and value-seeking (the highest level) characteristics (in line with the illustrating examples from R4 in 4.3.1 and 4.3.3), should it then be classified as proactive (the middle level)? If the same characteristic is related to several driving forces, such as compliance with public protest combined with long-term investments, how should that be handled? Should retailers even be value-seeking? Might it be more relevant for supply chain partners to understand and judge considerations and indicators - the what - than consciousness - the why? Are the driving forces for sustainability (consciousness) important or are the actual results (considerations and indicators) more interesting? These questions are of importance to address in future research.

We have used content analysis applied to CSR reports to fulfil our purpose and respond to our questions. Content analysis is useful for understanding three aspects; the text itself, the audience and the creator of the text (Tate et al., 2010). Our study has so far focused on the text itself; we will now discuss the audience. Sustainability reports should serve a function for both consumers and supply chain partners. We found lengthy reports, each with its own logic and structure. However, large reports are difficult to grasp and judge, in particular, we believe, for consumers. One of the most accessible reports has only 15 pages. It is called a sustainability brochure and was the only report publically accessible to, e.g., consumers. Retailers have a unique position in the supply chain as they have contacts both with suppliers and consumers (Spence and Bourlakis, 2009; Kolk et al., 2010; Kotzab et al., 2011; Wiese et al., 2012). As such, it seems to be a good idea for retailers to more clearly state for which stakeholder a specific sustainability report is intended.

The fact that purchasing is so emphasized in the sustainability reports makes us wonder about the third aspect in content analysis from Tate et al. (2010), the creator. Who creates sustainability reports? Professionals involved in purchasing, sustainability managers or maybe 
logistics managers? We were surprised to see that the sustainability reports do not contain that much logistics-related information. We ask, in line with Seuring and Müller (2008) and Abbasi and Nilsson (2012), what role does logistics play in the work towards sustainable development? We have studied non-producing companies to whom logistics should be even more central (Wiese et al., 2012). In addition, this is no average sample - we investigated the largest retailers in the world.

Finally we want to see what contingencies we can see in our sample, which possibly could explain the differing descriptions of considerations, indicators and consciousness. The size of the CSR report is touched upon above in relation to the audience. The longest CSR report does indeed show many considerations and indicators, but the best report in term of the number of considerations and indicators (R14) in the sample, is less than half the size of the longest report. R13 can be said to be the overall strongest report as it scores well in all three dimensions (considerations, indicators and consciousness). Most retailers in our sample are from the US, representing both higher and lower scoring reports. The best report overall is a Japanese report. Those reports that build upon GRI tend to be strong on the indicators side. As this study is limited to the retail industry, it is hard to evaluate external validity in terms similar or the same patterns are to be found within other industries. Based on our sample, we are not comfortable to formulate propositions on contingencies, but leave that for further research.

\section{CONCLUSIONS AND CONTRIBUTIONS}

The purpose of this study was to explore and illustrate ways in which the world's largest retailers describe their logistics-related environmental considerations, their environmental indicators applied to measure the effects of these considerations, and their environmental consciousness in their CSR reports. We find that few retailers show environmental considerations in all logistics activities, but that purchasing is well described. Even if many retailers claim to use the GRI framework, no one uses all the indicators in the framework. Environmental consciousness was difficult to judge in CSR reports. We have provided stateof-the-art descriptions of the world's largest retailers' work with logistics-related environmental sustainability, but found it difficult to understand the driving forces for environmental considerations and judge consciousness by studying CSR reports.

A contribution to theory is the development of two classification models. The first provides a description structure for environmental considerations related to logistics activities. The second expands the GRI indicator framework by incorporating a structure for logistics activities. These models enable continued research as suggested below. Practical contributions are made in showing how an understanding and judgment of supply chain partners can be achieved by studying accessible sustainability reports, which may be helpful and useful for managers and consumers. The classification models can also be used as environmental considerations and indicators checklists, which could be used for a retailer wishing to cover a broad scope logisticswise with their environmental sustainability work.

This study has its limitations. The classification model for considerations was developed from scratch and could have resulted in another, but similar, model. However, the logistics activities and indicators were based upon existing frameworks. There may be other sampling frames for large retailers than www.stores.org, but we feel confident that we have studied some of the largest retailers in the world. The search function in Adobe Acrobat was an important and useful tool, but it may also constitute a limitation. The greatest limitation is the difficulty in conveying how examples of considerations, indicators and consciousness were identified in the second, third and fourth search, a difficulty we tried to overcome by having three authors work on this process together until consensus was reached. We agree that it is a challenge to interpret, 
operationalize and measure environmentally sustainable development in supply chains (Abbasi and Nilsson, 2012), but we have made an attempt to clarify this process with our classification models. Furthermore, we have studied what the companies report in terms of logistics-related environmental sustainability, not necessarily what they actually do.

A large number of further studies are suggested. Continued analyses of the retailers in this study can be carried out, such as further studying background or contingency variables as the size of a CSR report, industry, the report's country of origin, related to the scope and depth of considerations and indicators. Another interesting question evoked during this study, is the possible alignment within each retailer among considerations, indicators and consciousness. We see, for example, R1, which is strong in both considerations and indicators, but does not show a value-seeking consciousness in its report. R10 showed a value-seeking consciousness but had fewer considerations and indicators. R13 is strong on all three dimensions. We want to believe that there should be an alignment between considerations and indicators, as companies should want to measure the effects generated by their environmental considerations. However, should there also be alignment with environmental consciousness?

Using the same methodological approach (studying CSR reports), the current study could be expanded to also cover the seldom investigated social considerations, indicators and consciousness related to logistics. Further studies about the role logistics play in the work towards sustainable development and in sustainability reports is also of interest. In what ways are logistics professionals and purchasing professionals involved in being creators of CSR reports? What dialogue occurs between the information/marketing creators of sustainability reports and those who are responsible for the contents? Are different professionals within a company such as marketers, category managers, even suppliers/brand owners competing for being mentioned within CSR reports? This topic could be investigated in a case study building upon deep access. Understanding a company's environmental consciousness was difficult while working from only a CSR report. Another deep case study of retailers could allow for better judgment and classification of consciousness and address such questions as whether the level of consciousness in logistics activities differs from the companies' overall level of consciousness.

\section{REFERENCES}

Abbasi, M. and Nilsson, F. (2012), "Themes and challenges in making supply chains environmentally sustainable”, Supply Chain Management; an International Journal, Vol. 17 No.5, pp. 517-530.

Abukhader, S.M. and Jönson, G. (2004),’Logistics and the environment: is it an established subject?”, International Journal of Logistics; Research and Applications, Vol. 7 No. 2, pp. 137149.

Aronsson, H. and Huge-Brodin, M. (2006), “The environmental impact of changing logistics structures, The International Journal of Logistics Management, Vol. 17 No. 3, pp. 394-415.

Ashby, A., Leat, M. and Hudson-Smith, M., (2012) "Making connections: a review of supply chain management and sustainability literature", Supply Chain Management: An International Journal, Vol. 17 No. 5, pp. 497-516.

Benn, S., Dunphy, D. and Griffiths, A. (2006), "Enabling change for corporate sustainability: an integrated perspective", Australasian Journal of Environmental Management, Vol.13 No. 3, pp. 156-165. 
Bernon, M., Rossi, S. and Cullen, J. (2011),’Retail reverse logistics: a call and grounding framework for research", International Journal of Physical Distribution \& Logistics Management, Vol. 41 No. 5, pp. 484-510.

Björklund, M. (2005), "Purchasing practices of environmentally preferable transport services, guidance to increased shipper consideration", $\mathrm{PhD}$ thesis, Department of Industrial Management and Logistics, Lund University, Lund.

Björklund, M. (2010), "Benchmarking tool for improved corporate social responsibility in purchasing”, Benchmarking: An International Journal, Vol. 17 No. 3, pp. 340-362.

Björklund, M. and Forslund, H. (2013),'The inclusion of environmental performance in transport contracts”, Management of Environmental Quality: an International Journal, Vol. 24 No.2, pp. 214-227.

Brindley, C. and Oxborrow, L. (2014), "Aligning the sustainable supply chain to green marketing needs: A case study”, Industrial Marketing Management, Vol. 43 No. 1, pp. 45-55. Bryman, A. and Bell, E. (2011), Business Research Methods, Oxford University Press.

Carbone, V., Moatti, V. and Vinzi, V. E. (2012), "Mapping corporate responsibility and sustainable supply chains: an exploratory perspective", Business Strategy and the Environment, Vol. 21 No. 7, pp. 475-494.

Carter, C.L. and Ellram, L. (1998), "Reverse logistics: A review of the literature and framework for future investigation”, Journal of Business Logistics, Vol. 19 No. 1, pp. 85-102.

Carter, C.L. and Jennings, M.M. (2004), "The role of purchasing in corporate social responsibility: a structural equation analysis”, Journal of Business Logistics, Vol. 25 No. 1, pp.145-186.

Closs, D.J., Speier, C. and Meacham, N. (2011), "Sustainability to support end-to-end value chains: the role of supply chain management", Journal of the Academy of Marketing Science Vol. 39 No. 1, pp. 101-116

ECR (2011), “Optimizing your supply chain by using standards”, available at: www.ecr-all. org/ecropedia (accessed April 20, 2012).

Elg, U. and Hultman, J. (2011), "Retailers' management of corporate social responsibility (CSR) in their supplier relationships - Does practice follow best practice?", The International Review of Retail, Distribution and Consumer Research, Vol. 21 No. 5, pp. 445-460.

Eng-Larsson, F., and Kohn, C. (2012), "Modal shift for greener logistics - the supplier's perspective”, International Journal of Physical Distribution \& Logistics Management, Vol. 42 No. 1, pp. 36-59.

Fernie, J., Sparks, L. and McKinnon, A.C. (2010), "Retail logistics in the UK: past, present and future”, International Journal of Retail \& Distribution Management, Vol. 38 No 11/12, pp. 894-914.

Forslund, H. (2014), "Exploring logistics performance management in supplier/ retailer dyads” International Journal of Retail \& Distribution Management, Vol. 42 No. 3, pp. 205-218.

Ganesan, S., George, M., Jap, S., Palmatier, R.W. and Weitz, B. (2009),’Supply chain management and retailer performance: emerging trends, issues and implications for research and practice”, Journal of Retailing, Vol. 85 No. 1, pp. 84-94.

Jones, P., Comfort, D. and Hillier, D. (2005a), “Corporate social responsibility and the UK’s top ten retailers” International Journal of Retail \& Distribution Management, Vol. 33 No. 12, pp. 882-892. 
Jones, P., Comfort, D., Hillier, D. and Eastwood, I. (2005b), "Retailers and sustainable development in the UK.” International Journal of Retail \& Distribution Management, Vol. 33 No. 3, pp. 207-214.

Kolk, A., Hong, P., and van Dolen, W. (2010), "Corporate social responsibility in China: an analysis of domestic and foreign retailers' systainability dimensions”, Business Strategy and the Environment, Vol. 19 No. 5, pp. 289-303.

Kotzab, H., Munch, H., Faultrier, B. and Teller, C. (2011), "Environmental retail supply chains: When Goliaths become environmental Davids", International Journal of Retail \& Distribution Management, Vol. 39 No. 9, pp. 658-681.

Marchant, C. (2010) "Reducing the environmental impact of warehousing". Chapter 8, pg 167192 In McKinnon, A., Cullinane, S., Browne, M. Whiting, A. (Ed.), Green Logistics Improving the environmental sustainability of logistics, Kogan Page, India.

Martinsen, U. and Björklund, M. (2012),"Matches and gaps in the green logistics market", International Journal of Physical Distribution \& Logistics Management, Vol. 42 No. 6, pp. 562-583.

McKinnon, A. (2010) Environmental sustainability: a new priority for logistics managers”. Chapter 1, pg 3-30 In McKinnon, A., Cullinane, S., Browne, M. Whiting, A. (Ed.), Green Logistics Improving the Environmental Sustainability of Logistics, Kogan Page, India.

McKinnon, A, and Edwards, J. (2009) "The greening of retail logistics”. In, Fernie, J. and Sparks, L. (Editors) Logistics and retail management: emerging issues and new challenges in the retail supply chain, Kogan Page, $3^{\text {rd }}$ edition.

Menachof, D. A., Bourlakis, M. A. and Makios, T. (2009), "Order lead-time of grocery retailers in the UK and Greek markets”, Supply Chain Management: An International Journal, Vol. 14 No. 5, s. 349-358.

Rogers, D.S and Tibben-Lembke, R. (2001), “An examination of reverse logistics practices” Journal of Business Logistics, Vol. 22 No. 2, pp. 129-148.

Sarkis, J.L., Meade, M., and Talluri. S. (2004), "E-logistics and the Natural Environment", Supply Chain Management, Vol. 9 No. 4, pp. 303-312.

Searcy, C. (2011), "Updating corporate sustainability performance measurement systems", Measuring Business Excellence, Vol. 15 No. 2, pp. 44-56.

Seuring, S. (2008), "Assessing the rigor of case study research in supply chain management", Supply Chain Management: An International Journal, Vol. 13 No. 2, pp.128-137.

Seuring, S. and Gold, S. (2012), "Conducting content-analysis based literature reviews in supply chain management”, Supply Chain Management: An International Journal, Vol. 17 No. 5, pp. 544-553.

Seuring, S. and Müller, M. (2008), "From a literature review to a conceptual framework for sustainable supply chain management”, Journal of Cleaner Production, Vol. 16 No. 15, pp. 1699-1710.

Shaw, S., Grant, D.B. and Mangan, J. (2010). "Developing environmental supply chain performance measures”, Benchmarking; an International Journal, Vol. 17 No. 3, pp. 320339.

Spence, L. and Bourlakis, M. (2009). "The evoluation from corporate social responsibility to supply chain responsibility”, Supply Chain Management: An International Journal, Vol. 14 No. 4, pp. 291-302.

Tate W., Ellram, L.M. and Kirchoff, J.F. (2010), “Corporate social responsibility reports: a thematic analysis related to supply chain management”, Journal of Supply Chain Management, Vol. 46 No. 1, pp. 19-44. 
van Hoek, R.I. (1999) "From reversed logistics to green supply chains”, Supply chain management, Vol. 4 No. 3, pp. 129-134.

Weijers, S., Glöckner, H.H., and Pieters, R. (2012), "Logistics Service Providers and Sustainable Physical Distribution”, LogForum, Vol. 8 No. 2, pp. 157-165.

Wiese, A., Kellner, J., Lietke, B., Toporowski, W. and Zielke, S. (2012), "Sustainability in retailing -a summative content analysis”, International Journal of Retail \& Distribution Management, Vol. 40 No. 4, pp. 318-335.

Wiese, A., Zielke, S, and Toporowski, W. (2015), "Sustainability in retailing - research streams and emerging trends”, International Journal of Retail \& Distribution Management, Vol. 43 No. $4 / 5$.

Wu, H. J. and Dunn, S. C. (1995), "Environmentally responsible logistics systems”, International Journal of Physical Distribution \& Logistics Management, Vol. 25 No. 2, pp. 20-38. Young, A. and Kielkiewicz-Young, A. (2001), "Sustainable Supply Network Management”, Corporate Environmental Strategy, Vol. 8 No. 3, pp. 260-268.

www.globalreporting.org/reporting/g4/Pages/default.aspx (accessed Dec 12, 2014)

www.stores.org (accessed Dec 12, 2014) 